\title{
Gambaran Pegawai Terkonfirmasi COVID-19 di Rumah Sakit Pusat Infeksi Sulianti Saroso Tahun 2020
}

\author{
Description of Employees Confirmed by COVID-19 at Sulianti Saroso Infectious Disease \\ Hospital in 2020
}

\author{
Anita PD Nugroho*, Herlina, Nunung Hendrawati, Siti Maemun, Intan Pertiwi, Farida \\ Murtiani, A. Dala Intan SN \\ Rumah Sakit Penyakit Infeksi Prof. Dr. Sulianti Saroso
}

*Korespondensi Penulis:

Anita PD Nugroho

Email: nita.pdn@gmail.com

\begin{abstract}
Abstrak
Latar Belakang: Tenaga kesehatan yang berada di garis depan penanganan COVID-19 berisiko tinggi terinfeksi COVID-19 sehingga hasil surveilans menjadi dasar strategi untuk melindungi tenaga kesehatan, menghambat penyebaran infeksi dan mengurangi risiko transmisi. Tujuan: Mengetahui gambaran pegawai yang terkonfirmasi COVID-19 di RSPI Sulianti Saroso tahun 2020 berdasakan data surveilans. Metode: Desain deskriptif cross-sectional, total sampel 173 sampel, data sekunder bersumber dari data hasil RTPCR dan data surveilans epidemiologi. Hasil: Kejadian infeksi COVID-19 dimulai pada bulan Maret 2020, puncak kasus pegawai tertinggi minggu ke-35, terbesar pada pegawai perempuan (60\%), rentang umur 2938 tahun (38\%), terbesar pada tenaga kesehatan perawat $(38 \%)$. Pegawai yang mengalami tanda \& gejala (58\%), melaksanakan isolasi mandiri $(63 \%)$ dan sembuh (98\%). Kesimpulan: Gambaran pegawai yang terkonfirmasi COVID-19 di RSPI Sulianti Saroso tahun 2020 dilihat berdasarkan jenis kelamin, umur, jenis ketenagaan, tanda dan gejala, tindak lanjut penanganan dan luaran.
\end{abstract}

Kata Kunci: COVID-19; Tenaga Kesehatan

\begin{abstract}
Background: Health workers who are at the forefront of handling COVID-19 are at high risk of being infected with COVID-19 so that the results of surveillance become the basis for strategies to protect health workers, inhibit the spread of infection and reduce the risk of transmission. The Purpose of study is knowing the description of employees who have confirmed COVID-19 at RSPI Sulianti Saroso in 2020 based on surveillance data. Method: Cross-sectional descriptive design, a total sample of 173 samples, secondary data sourced from RT-PCR data and epidemiological surveillance data. Results: The incidence of COVID19 infection began in March 2020, with the highest peak of employee cases in the 35th week, the largest in female employees (60\%), age range 29-38 years (38\%), the largest in health care workers (38\%). Employees who experience signs \& symptoms (58\%), carry out self-isolation (63\%) and recover (98\%) Conclusions: The description of employees who have confirmed COVID-19 at RSPI Sulianti Saroso in 2020 is seen by gender, age, type of workforce, signs and symptoms, follow-up handling and outcomes.
\end{abstract}

Keyword: COVID-19, Health Worker 


\section{Pendahuluan}

Pada 31 Desember 2019, WHO China Country Office melaporkan kasus pneumonia yang tidak diketahui etiologinya di Kota Wuhan Provinsi Hubei Cina. Pada tanggal 7 Januari 2020, Cina mengidentifikasi pneumonia yang tidak diketahui etiologinya tersebut sebagai jenis baru coronavirus dan WHO menamakan kasus pneumonia ini sebagai 2019-nCoV, namun pada tanggal 12 Februari 2020 WHO mengumumkan perubahan namanya sebagai COVID-19. Pada tanggal 30 Januari 2020 WHO menetapkan kejadian COVID-19 sebagai Kedaruratan Kesehatan Masyarakat Yang Meresahkan Dunia/ Public Health Emergency of International Concern (KKMMD/PHEIC) dan tanggal 11 Maret 2020 WHO mendeklarasikan COVID-19 sebagai Pandemi Global. ${ }^{1,2}$

Coronavirus Disease 2019 (COVID19) adalah penyakit menular yang disebabkan oleh Severe Acute Respiratory Syndrome Coronavirus 2 (SARS-CoV-2).

SARS-CoV-2 merupakan coronavirus jenis baru yang belum pernah diidentifikasi sebelumnya pada manusia. Coronavirus merupakan zoonosis (ditularkan antara hewan dan manusia). Penelitian menyebutkan bahwa SARS ditransmisikan dari kucing luwak (civet cats) ke manusia dan MERS dari unta ke manusia. Adapun, hewan yang menjadi sumber penularan COVID-19 ini masih belum diketahui. Setidaknya dua jenis coronavirus yang diketahui menyebabkan penyakit dan menimbulkan gejala berat antara lain Middle East Respiratory Syndrome (MERS) dan Severe Acute Respiratory Syndrome (SARS). ${ }^{1}$

Berdasarkan studi epidemiologi dan virologi, COVID-19 utamanya ditularkan dari orang yang bergejala (simptomatik) ke orang lain yang berada dalam jarak dekat melalui droplet (partikel berisi air dengan diameter $>5-10 \mu \mathrm{m})$. Penularan droplet terjadi ketika seseorang berada pada jarak dekat (dalam 1 meter) dengan seseorang yang memiliki gejala pernapasan (misalnya, batuk atau bersin) sehingga droplet berisiko mengenai mukosa (mulut dan hidung) atau konjungtiva (mata). Penularan juga dapat terjadi melalui benda dan permukaan yang terkontaminasi droplet di sekitar orang yang terinfeksi. Oleh karena itu, penularan virus COVID-19 dapat terjadi melalui kontak langsung dengan orang yang terinfeksi dan kontak tidak langsung dengan permukaan atau benda yang digunakan pada orang yang terinfeksi (misalnya, stetoskop atau termometer). Untuk transmisi melalui udara dapat dimungkinkan dalam keadaan khusus pada prosedur atau perawatan supportif yang menghasilkan aerosol. ${ }^{1}$ 
Transmisi penularan COVID 19 pada tenaga kesehatan menjadi isu penting di era pandemi ini. Infeksi dan kematian akibat COVID-19 pada petugas kesehatan merupakan suatu tragedi baik kepada individu, keluarga, rekan kerja dan merupakan krisis eksistensi pada tenaga kesehatan itu sendiri dan infrastruktur kesehatan baik lokal maupun nasional. Awal pandemi COVID-19 yang terjadi di Wuhan, China, pemerintah China melaporkan 3387 tenaga kesehatan terinfeksi COVID-19, 23 diantaranya meninggal dunia termasuk 21 orang dokter dan ahli bedah, 1 orang perawat dan 1 orang teknisi termasuk diantaranya seorang dokter mata dr. Li Wengliang yang merupakan dokter pertama yang memberi tahu munculnya wabah SARSCoV2 (COVID-19) di China. ${ }^{3,4}$

Tenaga kesehatan yang berada di garis depan dalam penanganan COVID19 berisiko tinggi mendapatkan infeksi COVID-19. Lebih dari 10\% dari kasus yang dilaporkan di Cina dan Italia adalah petugas kesehatan, di Spanyol 20,4\% dari kasus yang dikonfirmasi merupakan tenaga kesehatan. ${ }^{5}$ Center of Disease Control and Prevention (CDC) melaporkan per tanggal 9 Juni 2021, jumlah infeksi COVID-19 pada tenaga kesehatan di Amerika Serikat, sebesar 509.214 kasus dengan jumlah kematian sebesar 1.652 kematian. Sedangkan di
Indonesia, pada 2 Januari 2021 Ikatan Dokter Indonesia (IDI) pada melaporkan 504 tenaga kesehatan meninggal akibat COVID-19 sepanjang Maret-Desember 2020. 252 orang diantaranya dokter, 171 orang perawat, 64 orang bidan, 7 orang farmasi dan 10 orang petugas laboratorium. ${ }^{6,7}$

Petugas kesehatan memainkan peranan penting tidak hanya dalam manajemen klinis pasien tetapi juga dalam memastikan bahwa tindakan pencegahan dan pengendalian infeksi dapat diterapkan dengan baik di fasilitas pelayanan kesehatan. Oleh karena itu perlu untuk memahami bagaimana infeksi COVID-19 dapat terjadi diantara petugas kesehatan dan apa yang menjadi faktor risikonya, dengan tujuan dapat menemukan karakteristik pola penularan dan faktor risiko untuk mencegah terjadinya penularan antar petugas di masa mendatang dan untuk menemukan tindakan pencegahan dan pengendalian infeksi COVID-19 di fasilitas kesehatan. Hal inilah yang menjadi dasar dilakukannya surveilans pada tenaga. ${ }^{8}$

Pedoman Pencegahan dan Pengendalian COVID-19 Revisi Ke-5, menyebutkan tenaga kesehatan merupakan salah satu kelompok yang berisiko terinfeksi COVID-19 sehingga diperlukan strategi atau serangkaian kegiatan/ tindakan yang dapat dilakukan 
untuk membantu menghambat/ memperlambat penyebaran infeksi COVID-19 dengan tujuan melindungi tenaga kesehatan dan mengurangi risiko transmisi nosokomial. Salah satu strategi kegiatan yang diperlukan untuk penanggulangan infeksi COVID-19 pada tenaga kesehatan di fasilitas kesehatan yaitu melalui pelaksanaan surveilans epidemiologi pada tenaga kesehatan. ${ }^{1,9}$

Berdasarkan hal tersebut maka penulis memandang perlu melakukan pengkajian dasar yang memanfaatkan data surveilans pegawai yang terkonfirmasi COVID-19, sehingga diharapkan identifikasi masalah yang nyata di lapangan dapat diketahui. Kajian ini diharapkan dapat menghasilkan rekomendasi kajian lanjutan dalam mewujudkan translasional research, yang akan digunakan untuk pencegahan penularan infeksi COVID-19 pada pegawai.

\section{Metode}

Desain kajian ini deskriptif cross sectional, dengan data sekunder bersumber dari data hasil Real Time Polymerase Chain Reaction (RT-PCR) pegawai dilanjutkan dengan data surveilans epidemiologi.
Data hasil RT-PCR diperoleh dari Poli Medical Check Up (MCU) sedangkan data surveilans epidemiologi diperoleh dari Tim Surveilans Epidemiologi berupa data hasil wawancara/ investigasi petugas yang terkonfirmasi COVID-19. Terdiri dari 173 sampel dengan kriteria inklusi yaitu seluruh petugas yang terkonfirmasi COVID-19 dengan periode waktu tahun 2020. Kajian ini telah mendapat ethical clearance dari komite etik RSPI Prof Dr Sulianti Saroso dengan nomor izin etik 27/XXXVIII.10/IX/2021

Hasil

Gambaran Kasus COVID-19 Pada Pegawai Di RSPI Sulianti Saroso Tahun 2020

Gambaran kasus COVID-19 pada pegawai di RSPI Sulianti Saroso tahun 2020 berdasarkan jumlah pegawai yang terkonfirmasi COVID-19 dalam mingguan epidemiologi. Pada grafik ini pegawai RSPI Sulianti Saroso merupakan gabungan dari karyawan ASN maupun non ASN serta relawan tenaga kesehatan yang bertugas di RSPI Sulianti Saroso. Grafik menunjukkan puncak kasus tertinggi pada minggu ke-35 dan masih terjadi peningkatan kasus secara fluktuatif pada minggu ke 38, 43 dan 53 (Grafik 1). 


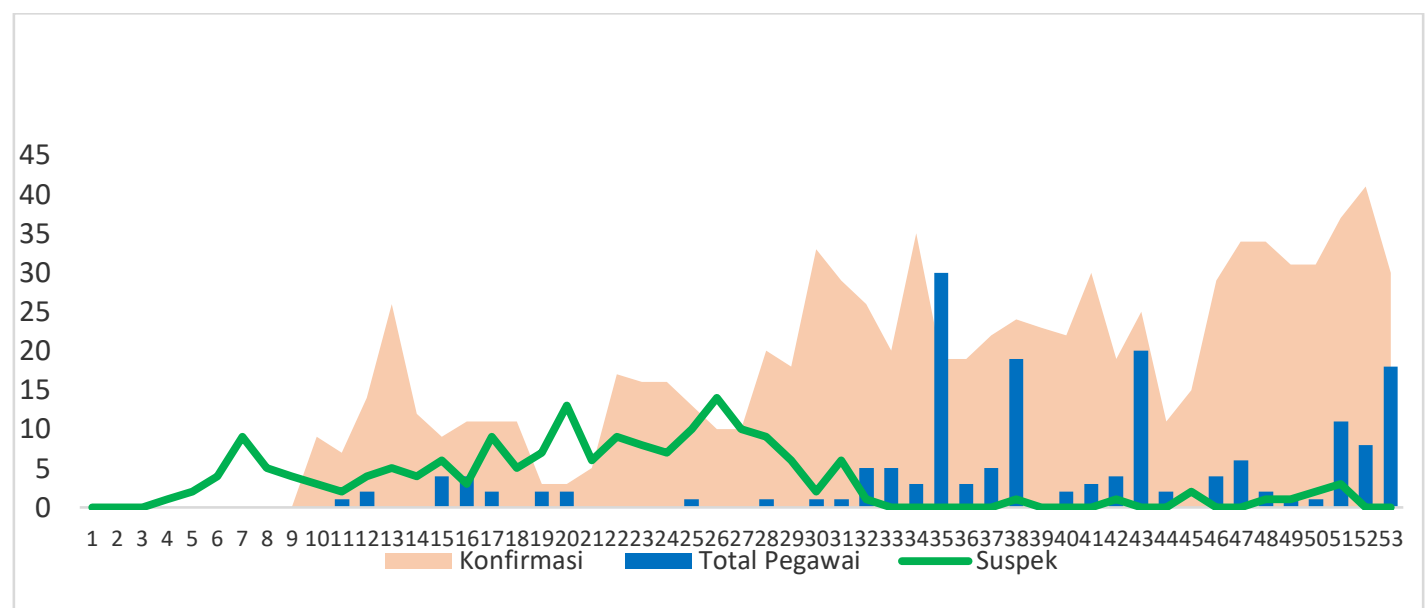

Grafik 1. Kejadian Infeksi COVID-19 Pada Pegawai Dalam Mingguan Epidemiologi dan Kriteria Kasus Pasien Yang Dirawat di RSPI Sulianti Saroso Tahun 2020

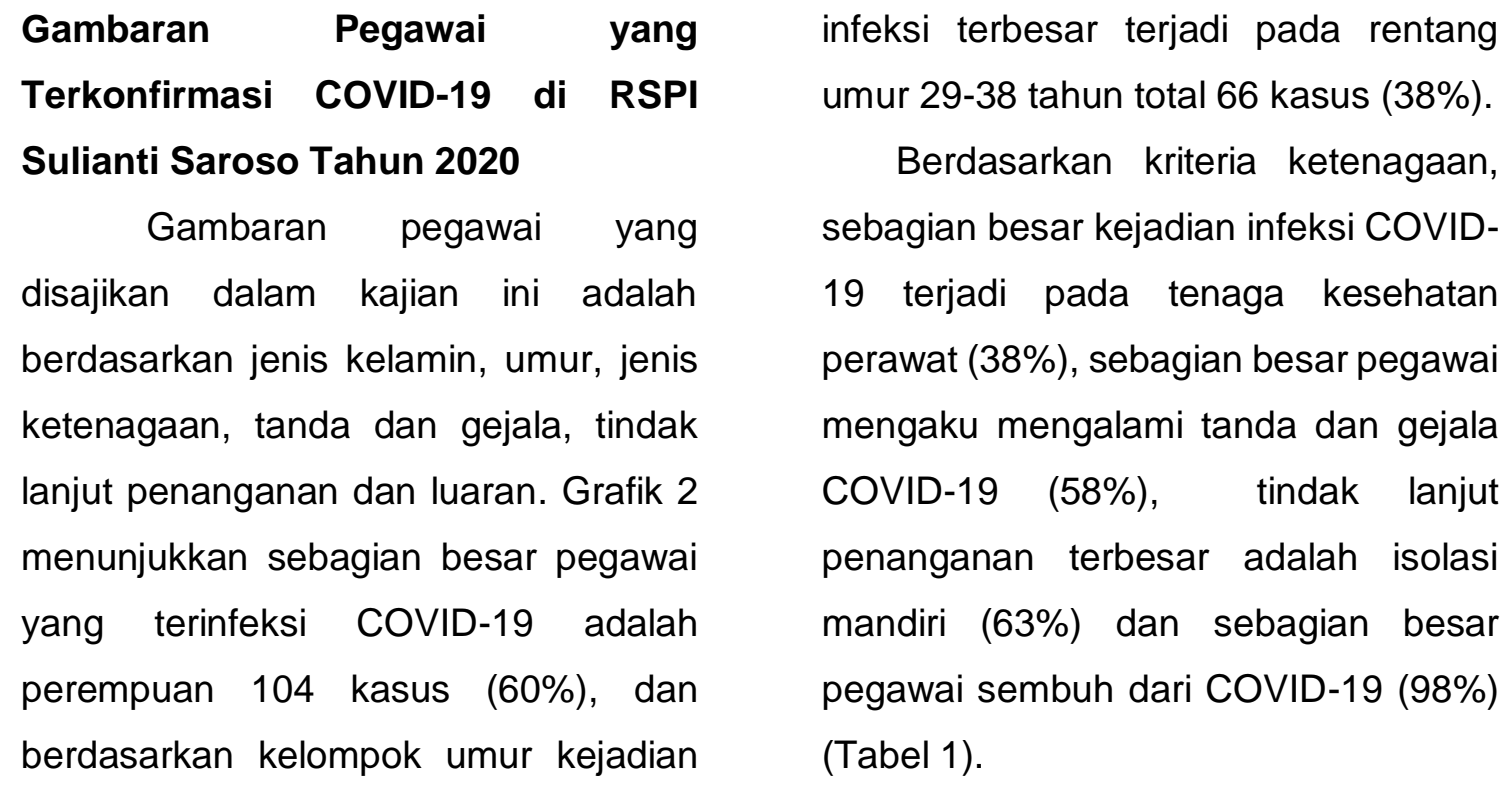

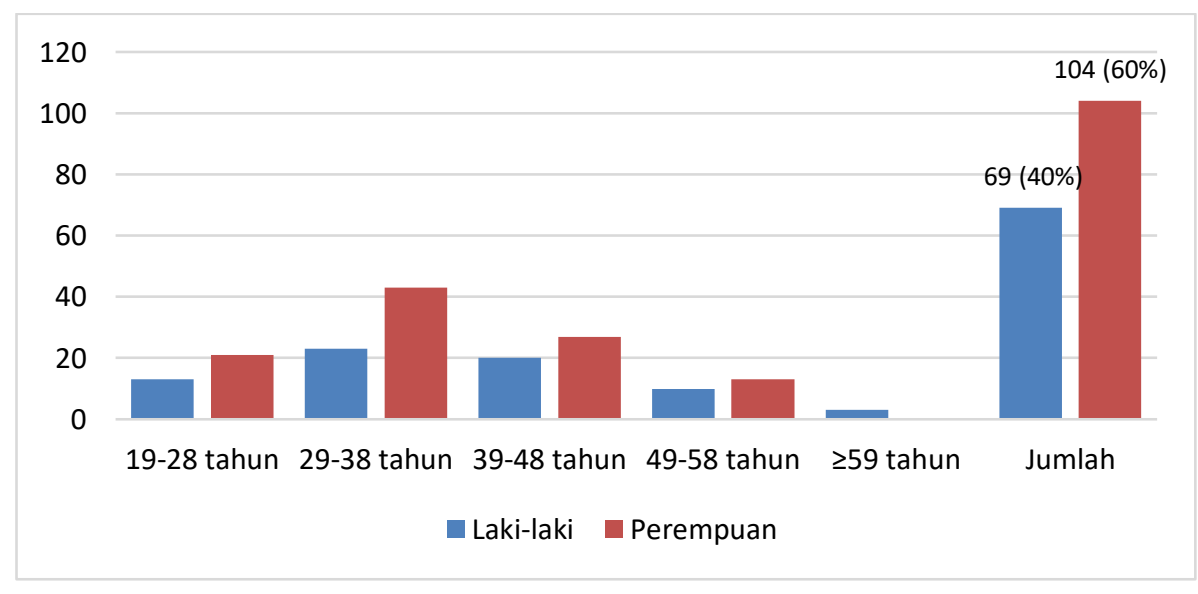

Grafik 2. Kasus Positif Pegawai Menurut Jenis Kelamin dan

Kelompok Umur Tahun 2020 
Tabel 1. Karakteristik: Jenis ketenagaan, tindak lanjut dan luaran

\begin{tabular}{lrc}
\hline Karakteristik & $\mathbf{n}$ & $\%$ \\
\hline Jenis Ketenagaan & & \\
Tenaga kesehatan dokter & 20 & 11 \\
Tenaga kesehatan perawat & 66 & 38 \\
Tenaga kesehatan lainnya & 46 & 27 \\
Non tenaga kesehatan & 41 & 24 \\
Tanda dan Gejala & & \\
Ada & 101 & 58 \\
Tidak ada & 72 & 42 \\
Tindak Lanjut Penanganan & & \\
Isolasi Mandiri & 109 & 63 \\
Rawat Inap & 64 & 37 \\
Luaran & & \\
Sembuh & 170 & 98 \\
Meninggal & 3 & 2 \\
\hline
\end{tabular}

\section{Pembahasan}

RSPI Sulianti Saroso merawat pasien terkonfirmasi COVID-19 dimulai dari awal pandemi COVID-19 di bulan Maret 2020. Kejadian infeksi pada pegawai juga mulai terjadi pada bulan Maret 2020. Relawan tenaga kesehatan mulai bertugas pada bulan April 2020 dan kejadian infeksi pada relawan mulai terjadi pada bulan Mei 2020. Kasus tertinggi keseluruhan pegawai terjadi pada bulan Agustus 2020, kasus belum mengalami penurunan secara persisten, tetapi masih fluktuatif yaitu naik kembali pada bulan Oktober dan Desember 2020.
Pada gambaran kasus COVID-19 pada pegawai di RSPI Sulianti Saroso tahun 2020 (Grafik 1) menunjukkan jumlah pegawai terkonfirmasi COVID-19 berdasarkan mingguan epidemiologi. Terlihat puncak kasus tertinggi pada minggu ke-35 yaitu bulan Agustus 2020 dimana di DKI Jakarta juga mulai mengalami kenaikan kasus. Pada minggu ke-35 ini jumlah kasus terbesar terjadi di unit Farmasi (13 kasus) dan unit Radiologi (7 kasus). Kasus yang terjadi dua unit ini adalah kasus klaster dengan dugaan adanya penularan lokal antar petugas pada rentang waktu yang berdekatan, kemungkinan dari pegawai yang terinfeksi COVID-19 namun tidak merasakan gejala tapi tetap bekerja dan berinteraksi dengan pegawai lainnya di unit kerjanya. Jumlah kasus yang cukup tinggi juga terjadi pada minggu ke-38 bulan September 2020 sebesar 19 kasus. Kasus yang terjadi secara sporadik atau tidak didominasi oleh unit kerja tertentu. ${ }^{1}$

Peningkatan kasus kembali pada minggu ke-43 bulan Oktober 2020 sebesar 20 kasus dengan klaster kasus terjadi di unit ICU (13 kasus). Di akhir tahun 2020 yaitu minggu ke-53, peningkatan kasus kembali terjadi dan klaster kasus terjadi di unit ICU (10 kasus) dimana sejumlah petugas ICU terinfeksi COVID-19 pada rentang waktu berdekatan dalam satu minggu. Selain 
unit ICU, kasus terbanyak juga terjadi di Laboratorium Penelitian (4 kasus).

Grafik 1 juga menghubungkan kejadian infeksi COVID-19 yang terjadi pada pegawai dengan kriteria kasus baru (insiden) pada pasien yang dirawat di RSPI Sulianti Saroso. Pada grafik 1 terlihat rawat inap kasus baru suspek yang berakhir dengan discarded semakin menurun setiap minggunya sedangkan kasus baru konfirmasi yang dirawat semakin meningkat. Peningkatan kasus rawat inap di RSPI Sulianti Saroso tahun 2020 juga sejalan dengan perkembangan kasus di DKI Jakarta yang terus menerus meningkat setiap minggunya sekalipun pemerintah provinsi DKI Jakarta telah menerapkan berbagai kebijakan pembatasan kegiatan di masyarakat. Penurunan kasus di DKI Jakarta baru terjadi di awal tahun 2021 sekitar minggu ke-6, hal tersebut terjadi oleh sejumlah upaya pemerintah dalam menekan laju transmisi di masyarakat, seperti gencarnya program Tracing yang diluncurkan Badan Nasional Penanggulangan Bencana (BNPB) bekerja sama dengan Kementerian Kesehatan RI sejak bulan November 2020 yang disebut sebagai pembongkaran gunung es kasus dan kontak erat, disertai gencarnya target testing pada masyarakat dan treatment serta pembatasan kegiatan masyarakat. ${ }^{14}$

Pada gambaran pegawai yang terkonfirmasi COVID-19 di RSPI Sulianti Saroso tahun 2020 berdasarkan kelompok umur dan jenis kelamin (Grafik 2), terlihat pegawai yang terinfeksi COVID-19 sebagian besar adalah perempuan sedangkan berdasarkan kelompok umur kejadian infeksi terbesar terjadi pada rentang umur 29-38 tahun, dan terdapat 3 orang pegawai laki-laki yang terinfeksi COVID19 dengan rentang umur $\geq 59$ tahun. Berdasarkan informasi dari Sub Bagian Administrasi Sumber Daya Manusia per Desember 2020, jumlah pegawai aktif antara lain pegawai perempuan sebesar 355 orang (58\%), dan jumlah pegawai laki-laki 253 orang (42\%). Jumlah pegawai perempuan terutama perawat lebih besar daripada pegawai laki-laki sehingga kejadian infeksi COVID-19 pada pegawai perempuan lebih besar daripada pegawai laki-laki.

COVID-19 menyerang semua kelompok umur dan jenis kelamin, walaupun secara informasi disebutkan lebih banyak terjadi pada laki laki. Dalam sebuah tinjauan literatur, penyakit komorbid hipertensi dan diabetes melitus, laki-laki, dan perokok aktif merupakan faktor risiko dari infeksi COVID-19. Distribusi laki-laki lebih banyak diduga terkait dengan prevalensi 
perokok aktif yang lebih tinggi daripada perempuan. ${ }^{10}$

Sebuah studi asosiasi faktor risiko COVID-19 kepada tenaga kesehatan di Spanyol menyebutkan variabel yang secara signifikan terkait tenaga kesehatan yang memerlukan perawatan (kasus COVID-19 yang berat) adalah jenis kelamin dan adanya pneumonia. Prevalensi COVID-19 antara pria dan wanita tidak berbeda, tetapi jenis kelamin pria dikaitkan dengan bentuk penyakit yang dapat berkembang lebih parah. ${ }^{5}$

Gambaran pegawai yang terkonfirmasi COVID-19 di RSPI Sulianti Saroso tahun 2020 berdasarkan jenis ketenagaan antara lain sebagian besar kejadian infeksi COVID-19 terjadi pada tenaga kesehatan perawat (38\%), diikuti oleh tenaga kesehatan lainnya (27\%) terdiri dari Radiografer, Apoteker dan Asisten Apoteker, TLM (Teknologi Laboratorium Medik), Perekam Medik, Fisioterapi, Teknisi dan Sanitarian. 24\% infeksi COVID-19 terjadi pada pegawai non tenaga kesehatan (Pekarya, Pegawai Laundry, Staf Manajemen, dll) dan $11 \%$ infeksi terjadi pada tenaga kesehatan dokter baik dokter umum maupun dokter spesialis.

Penyelidikan epidemiologi yang dilakukan pada pegawai terkonfirmasi COVID-19 menunjukkan penularan dari pasien ke perawat belum dapat dibuktikan terjadi, karena umumnya petugas telah melakukan Pencegahan dan Pengendalian Infeksi (PPI) sesuai standar. Jumlah perawat yang terinfeksi sebagian besar berasal dari klaster unit kerja dengan dugaan terjadi penularan antar petugas pada unit tertentu dalam kurun waktu yang sama atau berdekatan. Selain perawat, sejumlah tenaga kesehatan lainnya juga menyumbang kasus klaster seperti pada unit penunjang Farmasi dan Radiologi. Kejadian klaster yang terjadi pada kedua unit penunjang ini diduga berasal dari pegawai yang terinfeksi dari luar rumah sakit dan tidak merasakan gejala lalu bekerja seperti biasa disertai kemungkinan kurangnya kewaspadaan yang mengakibatkan terjadi penularan antar petugas.

Wang dalam Journal of Hospital Infection menyebutkan alasan terjadinya infeksi COVID-19 pada tenaga kesehatan di China antara lain kewaspadaan perlindungan diri petugas belum cukup kuat pada awal pandemi, lama waktu petugas terpajan ke sejumlah pasien yang terinfeksi COVID19, intensitas kerja, kurangnya istirahat sehingga meningkatkan risiko infeksi kepada petugas serta kurangnya Alat Pelindung Diri (APD). ${ }^{11}$ Sedangkan AlDelaimy menyebutkan dari skrining COVID-19 pada tenaga kesehatan yang dilakukan di 12 rumah sakit di Mesir, 
98\% tenaga kesehatan melaporkan kontak dengan kasus terjadi di rumah sakit bukan di masyarakat. ${ }^{12}$

Sebaliknya, Jacob dalam penelitian faktor risiko yang berhubungan dengan seropositivity SARS-CoV2 pada tenaga kesehatan di Amerika Serikat menyebutkan paparan dari luar tempat kerja (fasilitas kesehatan) merupakan faktor risiko paling besar terhadap terjadinya seropositivity SARS-CoV2 pada tenaga kesehatan dan tidak satu pun dari faktor dari tempat kerja yang dapat dikaitkan dengan seropositif tenaga kesehatan. ${ }^{13}$

Diharapkan dalam kajian selanjutnya dapat melihat penyebab atau hubungan berbagai faktor terhadap kejadian infeksi dan risiko penularan antar petugas seperti kepatuhan dalam penerapan protokol kesehatan, kelelahan, faktor fisik ruangan dan lainlain.

Gambaran pegawai yang terkonfirmasi COVID-19 di RSPI Sulianti Saroso tahun 2020 berdasarkan tanda dan gejala dan tindak lanjut penanganan antara lain berdasarkan data hasil penyelidikan epidemiologi, didapatkan hasil sebagian besar pegawai mengalami gejala COVID-19, antara lain demam, batuk, pilek, sakit tenggorokan, sakit kepala, nyeri otot dan sesak, terdapat dua kasus yang mengalami ruam kulit (kaligata). Pada pegawai yang terkonfirmasi COVID-19 dilakukan penanganan berupa isolasi mandiri $(63 \%)$ dan rawat inap (37\%) bagi yang memerlukan rawat inap. RSPI Sulianti Saroso menyiapkan ruang isolasi mandiri di rumah sakit bagi pegawai yang tidak dapat melakukan isolasi mandiri di rumah, selain penanganan buat pegawai, RSPI Sulianti Saroso juga memfasilitasi swab PCR pada anggota keluarga yang merupakan kontak erat dari pegawai tersebut dan dilakukan pelaporan ke Dinas Kesehatan Wilayah untuk pemantauan lebih lanjut pada keluarga pegawai yang juga terinfeksi COVID-19.

Gambaran pegawai yang terkonfirmasi COVID-19 di RSPI Sulianti Saroso tahun 2020 berdasarkan luaran atau kondisi akhir dari seluruh pegawai RSPI Sulianti Saroso yang terkonfirmasi COVID-19 yaitu sebagian besar pegawai sembuh dari COVID-19 namun terdapat 3 orang pegawai yang meninggal dunia yaitu satu orang dokter, satu orang perawat dan satu orang tenaga kesehatan lainnya (Teknisi Elektromedik). Ketiga tenaga kesehatan tersebut berjenis kelamin laki-laki dengan rentang umur 29-38 tahun sebanyak 2 orang dan $\geq 59$ tahun sebanyak 1 orang. Adapun rentang waktu kematian kepada ketiga tenaga kesehatan ini antara lain pada bulan April (perawat) dan Oktober (teknisi 
elektromedik) dan Desember (dokter).

Diharapkan di kemudian hari RSPI

Sulianti Saroso tidak lagi kehilangan tenaga kesehatan oleh karena COVID19.

Keterbatasan kajian ini adalah data bersumber dari data sekunder dimana informasi epidemiologi didalamnya juga memiliki keterbatasan yang disebabkan kurangnya keterbukaan informasi dari pergawai yang terkonfirmasi. Namun kelebihan kajian ini antara lain dapat menggambarkan kejadian infeksi COVID-19 pada pegawai di RSPI Sulianti Saroso dan menjadi dasar bagi kajian lanjutan yang akan digunakan untuk pencegahan penularan infeksi COVID-19 pada pegawai.

\section{Kesimpulan}

Kejadian infeksi COVID-19 pada pegawai di RSPI Sulianti Saroso dimulai pada bulan Maret 2020 dan hingga akhir tahun 2020 kenaikan kasus masih fluktuatif dan terdapat tiga kematian pada tenaga kesehatan sepanjang tahun 2020 di RSPI Sulianti Saroso. Adanya klaster kasus di beberapa unit kerja menguatkan dugaan adanya transmisi antar petugas namun tetap diperlukan analisis dan penelitian lebih lanjut untuk membuktikan hal tersebut.

\section{Saran}

Diharapkan dapat dilakukan surveilans berkelanjutan di tahun 2021 pada seluruh pegawai yang terkonfirmasi COVID-19 di RSPI Sulianti Saroso dan dapat dilakukan analisis dan penelitian lebih lanjut terkait kejadian infeksi COVID-19 pada pegawai di lingkungan kerja RSPI Sulianti Saroso yang melibatkan unit lainnya seperti K3 RS, Kesling, PPI, IPS RS dan lain-lain untuk memperkuat hasil analisisnya.

\section{Ucapan Terima Kasih}

Penulis mengucapkan terima kasih kepada Direktur Utama beserta seluruh jajaran Direksi RSPI-SS atas izin dan dukungan yang diberikan dan juga kepada semua pihak yang berkonstribusi dalam kajian ini.

\section{Daftar Pustaka}

1. Kementerian Kesehatan RI. Pedoman Pencegahan dan Pengendalian Corona Virus deases (Covid-19). Kementrian Kesehat [Internet]. 2020;5:178. Available from: https://covid19.go.id/ storage/app/media/Protokol/REV05_Pedoman_P2_COVID19_13_Juli_2020.pdf 
2. Burhan E, Susanto AD, Nasution SA, Ginanjar E, Pitoyo CW, Susilo $A$, et al. PEDOMAN TATALAKSANA COVID-19 Edisi 3 TIM EDITOR Perhimpunan Dokter Paru Indonesia (PDPI) Perhimpunan Dokter Spesialis Kardiovaskular Indonesia (PERKI) Perhimpunan Dokter Spesialis Penyakit Dalam Indonesia (PAPDI) Perhimpunan Dokter Anestesiologi dan Terap. 2020. 3-6, 88-89 p.

3. Erdem H, Lucey DR. Healthcare worker infections and deaths due to COVID-19: A survey from 37 nations and a call for WHO to post national data on their website. Int $\mathrm{J}$ Infect Dis. 2021;102(20):239-41.

4. Petersen E, Hui D, Hamer DH, Blumberg L, Madoff LC, Pollack M, et al. Li Wenliang, a face to the frontline healthcare worker. The first doctor to notify the emergence of the SARS-CoV-2, (COVID-19), outbreak. Int $J$ Infect Dis. 2020;93(February):205-7.

5. Algado-Sellés N, Gras-Valentí $P$, Chico-Sánchez P, Mora-Muriel JG, Soler-Molina VM, HernándezMaldonado $\mathrm{M}$, et al. Frequency, Associated Risk Factors, and Characteristics of COVID-19 Among Healthcare Personnel in a Spanish Health Department. Am J Prev Med. 2020;59(6):e221-9.
6. Centers for Disease Control and Prevention. COVID Data Tracker. United States COVID-19 Cases Deaths by State [Internet]. 2021;115. Available from: https://covid.cdc.gov/covid-datatracker/\#datatracker-home

7. Rate M, Workers H, Drops F. IDI: Covid-19 Mortality Rate of Health Workers in February Drops by $63 \%$ NEJM Knowledge +. 2021;4-7.

8. WHO. termasuk penjangkauan dan kampanye, dalam konteks pandemi COVID-19 Panduan interim. 2020;

9. Tim Kerja Kementerian Dalam Negeri. Pedoman Umum Menghadapi Pandemi Covid-19 Bagi Pemerintah Daerah: Pencegahan, Pengendalian, Diagnosis dan Manajemen. J Chem Inf Model. 2013;53(9):1689-99.

10. Susilo A, Rumende CM, Pitoyo CW, Santoso WD, Yulianti $M$, Herikurniawan $\mathrm{H}$, et al. Coronavirus Disease 2019: Tinjauan Literatur Terkini. J Penyakit Dalam Indones. 2020;7(1):45.

11. Wang J, Zhou M, Liu F. Reasons for healthcare workers becoming infected with novel coronavirus disease 2019 (COVID-19) in China. $J$ Hosp Infect [Internet]. 2020;105(1):100-1. Available from: https://doi.org/10.1016/j.jhin.2020.0 3.002 
12. Al-Delaimy WK. Commentary:

Challenges of COVID-19 screening of health care workers in Egypt and the Eastern Mediterranean region. Int J Epidemiol. 2021;50(1):62-3.

13. Jacob JT, Baker JM, Fridkin SK, Lopman BA, Steinberg JP, Christenson $\mathrm{RH}$, et al. Risk Factors Associated with SARS-CoV-2 Seropositivity among US Health Care Personnel. JAMA Netw Open. 2021;4(3):1-13.

14. https://www.antaranews.com/ berita/ 1986916/1427-relawan-bnpbbantu-tracing-covid-19-di-jakarta. 